This is a pre-print of an article published in Industrial Management \& Data Systems. The final authenticated version is available online at:

Berbegal-Mirabent, J.; Mas-Machuca, M.; Marimon, F. (2016). Antecedents of online purchasing behaviour in the tourism sector. Industrial Management \& Data Systems, 116(1): 87-102. https://doi.org/10.1108/IMDS-05-2015-0213

\title{
Antecedents of online purchasing behaviour in the tourism sector
}

Purpose - The aim of the paper is twofold. First, it investigates antecedents of on-line purchasing behavior, taking into account the relationships between the constructs of service quality, perceived value and loyalty. Second, the study analyses up to what point men's and women's behaviors are similar.

Design/methodology/approach - A survey was sent to the general public in Spain. Respondents were required to be consumers of online travel agencies. 1201 valid questionnaires were collected. No gender bias was detected in the sample. The data were analyzed through Structural Equation Modelling (SEM) to assess the proposed model. To determine non-invariant parameters across the two groups (men and women), a test for invariance was conducted.

Findings - Both functional quality and hedonic quality are shown as antecedents for perceived value, and, in turn, perceived value impacts loyalty. The impact of loyalty on purchasing behavior is significant, though weak. Gender differences are also examined and all parameters of the model are found to operate equivalently among men and women, indicating that both groups perform similarly.

Practical implications - This paper highlights that the hedonic dimension of quality is important in adding value for customers. Accordingly, managers should reinforce this dimension and include it in their business strategy.

Originality/value - Although the link between perceived quality and value-loyalty is well-established, there are still few studies that expand this link upstream or downstream. This paper analyzes the next link in this chain.

Keywords - e-service quality, tourism industry, e-commerce, hedonic quality, functional quality, perceived quality, loyalty, purchasing behavior

Paper type - Research paper 


\section{Introduction}

E-commerce is growing worldwide and virtual companies have major economic potential (Guo and Barnes, 2009). In particular, there are a number of forces encouraging firms operating in the tourism industry to adopt successful e-business models (Wang et al., 2002). According to Chiu et al. (2014), customer loyalty and repurchasing behaviour is critical for the survival and success of online stores.

Service quality is a client's subjective comparison between service expectations and perceived standard of delivery; that is, the difference between what customers wish and current service performance (Mouakket and Al-hawari, 2012; Parasuraman et al., 1988). Currently, service quality has achieved a strategic importance among businesses. To provide excellent service, it is important to exceed the expectations of the customers. It is therefore essential for online companies to improve service quality and, by extension, to build brand awareness that leads to a sound reputation.

Within the e-commerce environment, quality has become one of the critical determinants of success (Carlson and O'Cass, 2010; Kim et al., 2009). Some authors, such as Lee and Lin (2005) and Zeithaml et al. (2002) define e-service quality as customers' perceptions and judgments regarding the excellence and quality of an eservice delivery in an online shopping website.

Measuring service quality is a challenging task because customer satisfaction is determined by many intangible factors. Service quality has many psychological features and often extends beyond the immediate encounters, as it may have an impact on a person's future quality of life. Previous research on service quality measures have approached this construct in a number of ways, with studies examining website quality (Kuo, 2003), satisfaction with e-commerce channels (Devaraj et al., 2002), factors that lead to website success (Liu and Arnett, 2000), dimensions or features of service quality (Cristobal et al., 2007; Madu and Madu, 2002), and the influence of virtual communities on service quality (Zha et al., 2014).

On one hand, it is difficult to agree on one way of measuring service quality. On the other hand, consensus is found among researchers when determining the importance that the customer places on a service, particularly in online services. Customers' demands are rapidly evolving. As a result, companies operating online should be able to develop a user-friendly interface that guides the customer throughout the entire purchasing process. They are also expected to implement quality standards, not only in 
the process but also in the delivery. These strategies may help reduce the uncertainty and risk that many users still perceive when purchasing online.

In the tourism sector, when a tourist faces a new purchasing decision, quality is one of the most important variables to take into account (Moliner et al., 2007). As noted above, the online customer is increasingly demanding higher quality standards. These demands are even greater when the object of the purchase has a high component of intangibility. Firms should be able to respond to these demands in order to retain customers. With the rapid expansion of social networks and web 2.0, users can easily share their opinions about their experiences, influencing other users' purchasing decisions. Additionally, the Internet allows for rapid comparisons among competitors, facilitating moving from one supplier to another with no additional cost for the user.

Based on these reasons, and considering the dynamism of the online world, it is of great importance for firms to continuously update how quality is assessed. Moreover, eservice quality is a relevant driver of increased sales. Therefore, further research should be conducted to analyse its impact on specific constructs that have been linked to eservice quality, such as loyalty and customer purchasing behaviour (Iliachenko, 2006).

To fulfil this gap, this paper uses the service quality scale developed by Bernardo et al. (2012) that has been recently validated in the context of online travel agencies. Based on an in-depth literature review and taking as a basis the paper of Ho and Lee (2007), Bernardo et al. (2012) validate the impact that perceived value has over loyalty. Anchored in this prior research, this study aims at expand the model tested by these authors by adding a new construct: behaviour. Accordingly, consumer purchasing behaviour is introduced as the last link in the chain "quality, perceived value, loyalty and behaviour". It is important to remark that this paper stresses the importance of assessing the impact of service quality on real purchasing behaviour (not intention) through others constructs such as perceived value and loyalty.

To the best of the authors' knowledge, very few papers have analysed the relationship between e-service quality and real purchasing behaviour (Marimon et al., 2010). Therefore, this paper aims to contribute to the literature by providing new empirical evidence of this relationship. The analysis also includes the study of potential gender differences between men and women. The empirical application considers online travel agencies operating in Spain.

The structure of the article is as follows. Section 2 sets the theoretical underpinnings that support the hypotheses. Section 3 follows with the methodology. 
Next, Section 4 displays the results. The discussion of the results is presented in Section 5. Lastly, Section 6 comprises the conclusions along with the limitations and indications for future research.

\section{Literature review and hypotheses}

Petnji et al. (2012) conducted a review of applications and adaptations of the E-SQUAL scale since its publication in 2005 (Parasuraman et al., 2005). This scale quickly became very popular, with an even faster diffusion than Servqual, which was published in the mid-1980s (Parasuraman et al., 1988). Since 2005, customers' demands have evolved and are more stringent than ever, fostered by the rapid expansion of new technologies. Seven years later, Bernardo et al. (2012) proposed an updated and expanded scale to assess service quality in the context of e-commerce, and particularly in online travel agencies. This e-service quality scale includes four functional dimensions of the E-S-QUAL scale: (i) efficiency (six items); (ii) system availability (two items); (iii) fulfilment (six items); and privacy (three items).

However, the relationship between quality and perceived value has been extensively proved in the literature (Alonso-Almedia, et al. 2014; Bernardo et al., 2012; Boshoff, 2007; Marimon et al., 2010, 2012). According to this adaptation of e-quality and perceived value, the following hypothesis was made:

Hypothesis 1: Higher levels of functional quality in a website are positively related to higher levels of perceived value.

Hedonic quality can be defined as the value obtained by consumers from finding and purchasing a specific good or service (Chitturi et al., 2008). According to Hirschman and Holbrook (1982), hedonic value in online shopping has some parallels to the classic shopping experience, deployed in multisensory, fantastic and emotive aspects. Some authors, such as Bernardo et al. (2012), Hausman and Siekpe (2009), and Vázquez-Casielles et al. (2009), studied the "hedonic construct" as a dimension of quality. Similarly, Bridges and Florsheim (2008) identify utilitarian and hedonic values as the online shopping objectives that orient consumer behaviour. Nevertheless, this dimension of quality has not yet received much attention, especially in the e-commerce setting. 
The recent hedonic quality scale of Bernardo et al. (2012) is used, consisting of five measures, to assess the relationship between hedonic quality and perceived value. The following hypothesis emerges:

Hypothesis 2: Higher levels of hedonic quality in a website are positively related to higher levels of perceived value.

Loyalty can be related to a positive attitude that may lead to a repeat purchase, in terms of acquiring the same product/service or being loyal to a particular firm (buying new products/services, but from the same supplier). In the online context, many definitions can be found. Anderson and Srinivasan (2003: pp. 125) define loyalty as a “customer's favourable attitude toward an electronic business which leads buying behaviour". Similarly, Luarn and Lin (2003: pp. 157) refer to this construct as "the intention of a consumer to repurchase products/services through a particular e-service vendor", while Cyr et al. (2005) consider loyalty as perceived loyalty towards a website, with the intention of revisiting the site or buying from it in the future. More recently, Solano-Lorente (2013: pp. 107) states that loyalty is "the favourable attitude of the end user towards an online service that results in repeat use behaviour".

Perceived value can be considered a trade-off between the benefits and sacrifices perceived by customers in the suppliers' offering (Chang et al., 2009). Previous works have suggested that perceived value has a direct and significant influence on loyalty and e-shopping (Chiou and Shen, 2006; Enzmann and Schneider, 2005; Forsythe et al., 2006; Fuentes-Blasco et al., 2010; Ribbink et al., 2004). Going a step further, Boshoff (2007) studied loyalty as an antecedent of perceived value, and showed that E-S-QUAL tool is a valid and reliable scale to measure quality in the electronic service shopping context.

This relationship has also been validated in the tourism sector (e.g., Gallarza and Gil, 2006). Chang et al. (2009) confirms this hypothesis, observing significant moderating effects of customers' perceived value on the relationship between satisfaction and loyalty. These authors conclude that perceived value leads to loyalty in a website by decreasing an individual's need to look for different service providers. If the perceived value is high, customers will be less likely to switch to competing sites.

According to Moliner et al. (2007), perceived value and quality are two of the main aspects for a travel agency that allow it to capture a customer's loyalty. Based on the above arguments, hypothesis 3 follows: 
Hypothesis 3: Higher levels of perceived value in a website are positively related to higher levels of loyalty.

In the traditional offline world, it has been found that loyalty has a strong impact on purchasing intention (Chi et al., 2009; Hawes and Lumpkin, 1984; Sproles and Kendall, 1986). According to Bowen and Shoemaker (1998), loyalty is one of the most important antecedents of purchasing behaviour and the act of repurchasing. This statement also applies for e-commerce.

Following Nam et al.'s (2011) definition, loyalty refers to the psychological commitment that a consumer makes in the act of purchasing. This commitment may translate to the intention to purchase or to recommend; however, it does not necessarily imply the act of repurchasing. Consumers tend to buy familiar or well-known products, as they feel more confident with what they are actually purchasing (Chi et al., 2009; Macdonald and Sharp, 2000). Likewise, a positive word of mouth is also found to be essential and may help to generate brand awareness (Kim et al., 2004).

In the context of online travel agencies, several studies have examined consumer purchasing behaviour. One example is Lang (2000). This author suggests that, while travel consumers are increasingly turning to the Internet, many of them are still reluctant to book online, preferring more conventional distribution channels. In such cases, the Internet is used as a way of obtaining information, but very few users that accessed the website regularly book online. These findings highlight the existence of different behavioural pathways between purchasers and non-purchasers; consequently, they should be considered separately.

Indeed, in the literature, there is no consensus on how to best proxy the purchasing behaviour of consumers. While some authors use purchasing intention (regardless whether they purchase or not), some others use actual purchases.

The first group of studies includes those that postulate that consumer purchase intentions provide an acceptable proxy for actual online purchasing behaviour. According to Venkatesh and Davis (2000), intention does not represent a serious shortcoming, because there is substantial evidence supporting the existence of a causal link between intention and behaviour. Examples using this approach include the work of Jeong et al. (2003), who use a two-item, 7-point Likert scale to proxy customer's likelihood of buying in a particular online store. These items are: "If I purchase books in the next 30 days, I will use the online bookstore" and "I strongly recommend that others 
use the online bookstore". Using the same scale, another example can be found in Lee and Lin (2005). In this case, the authors examine the relationship between e-service quality dimensions and overall service quality, customer satisfaction and purchase intentions.

Contrary, a second group of authors suggests that purchasers and non-purchasers behave differently. For instance, Yang and Jun (2002) found that purchasers and nonpurchasers follow different patterns of behaviours with regard to the evaluation of service quality. Therefore, if the main objective is to analyse purchasing behaviour, actual purchase should be considered instead of the willingness of the consumer to purchase. Following this approach, it is worth mentioning the work of Bowen and Shoemaker (1998). In this study the authors developed a conceptual model of an online virtual community that linked the constructs of loyalty and travel product purchases. In this case, the purchasing behaviour was captured through the number of purchased travel products from the company.

Linking the constructs of loyalty and purchasing behaviour, Huang (2008) found that loyalty to a web-based travel agency resulted in an increased intention to purchase from that agency. In the online supermarket setting, Marimon et al. (2010) tested the link from quality to purchasing behaviour through perceived value and loyalty. In this case, the construct of actual purchasing behaviour was operationalised through two indicators: the value (total amount) and frequency (number of orders) of purchases made.

For the purpose of this study, this second approach is used, considering actual purchasing behaviour. Specifically, consumers' purchasing behaviour is captured through the number of orders made by a customer during the previous year. By adopting this approach, a significant and positive relationship is expected between loyalty and purchasing behaviour:

Hypothesis 4: Higher levels of loyalty to a website are positively related to higher levels of purchasing behaviour.

The resulting model is presented in Figure 1. As shown, the research model assumes a positive relationship between the two dimensions of quality (functional and hedonic) with perceived value. A positive relationship between perceived value and loyalty is also proposed. Likewise, a positive relationship is expected between the latter (loyalty) and consumer purchasing behaviour. 
Insert Figure 1 about here

According to Kumar and Varshney (2012) and Palan (2001), there is a need for further studies that address gendered perspectives in the area of marketing and, more importantly, in the literature on consumer behaviour. Following this suggestion, the study of gender differences is also introduced in the proposed model. To do this, the potential differences between women and men in online purchasing behavior are thus explored.

Previous research in this field indicates that dissimilar behavioural paths are observed between men and women (Weiser, 2000). This research showed that males mainly use Internet for entertainment and leisure, while women use it for interpersonal communication and educational purposes.

In the context of e-commerce, Bartel Sheehan (1999) found that males and females use computers in a different way, with women being more cautious in online shopping. Similarly, Rodgers and Harris (2003) found that women are less satisfied than men online shopping. The underlying rationale behind this result is explained by differences in perceived emotional benefits, trust and convenience. In terms of managerial implications, the aforementioned authors recommend that marketers reinforce emotional issues with female shoppers.

As highlighted above, some studies have suggested differences between men and women with respect to e-commerce behaviour. Nevertheless, another bulk of studies can be found supporting the hypothesis that there are no differences. For instance, researchers such as Kolsaker and Payner (2002) or Lian and Yen (2014) demonstrate that there are only marginal and insignificant gender differences in perceptions of ecommerce. As e-commerce is currently growing exponentially, consumers in general (female and male) use and perceive e-service quality in a very similar manner. In this direction, Davis et al. (2014) suggest that there is no online gender effect on hedonic shopping motivation and purchase intentions. Adopting this approach, hypothesis 5 is formulated as follows:

Hypothesis 5: There is no significant gender differences (between men and women) in the hypothesised relationships expressed in the model. 


\section{Methodology}

A survey was sent in 2010 and 2011. The questionnaire was divided in six main sections. The first section gathers demographic data from respondents. Sections 2 to 5 use the same items as the ones validated by Bernardo et al. (2012). For each dimension, items are based on a 5-point Likert scale, ranging from strongly disagree (1) to strongly agree (5). Table 1 presents the detailed questionnaire. Functional quality is compounded of 9 items. Hedonic and perceived quality, are both based on a 5 items scale. Next dimension refers to loyalty and includes 4 items. The survey ends with a last section concerning the purchasing behaviour of consumers. Particularly, behaviour was measured using one observed variable. Respondents were asked to answer the following question: How many times have you purchased on this site over the last year?

A specialised marketing research company was in charge of conducting the fieldwork. The survey was administered by telephone to the general public in Spain, so that the final sample was in accordance with the target audience. For inclusion, respondents were required to be consumers of online travel agencies. 1201 valid questionnaires were collected. No gender bias was detected in the sample (598 surveys were completed by men and 603 by women). The majority (55.8\%) of the respondents were under 35 years old. The educational level of the sample was high, with two-thirds of the respondents having a university degree. The average number of purchases made by each respondent from online travel agencies in the preceding year was 3.09.

The model (Figure 1) was tested using structural equations modelling (SEM). The structural model was estimated by using the maximum likelihood method from the asymptotic variance-covariance matrix. EQS Version 6.1 was the software used to compute the empirical work.

\section{Results}

Table 1 shows the reliability analysis for the four scales.

Insert Table 1 about here

Based on the figures reported in Table 1, it can be concluded that the four constructs are reliable in terms of the classic thresholds of Cronbach's alpha $(<0.7)$, 
composite reliability $(>0.7)$ and average variance extracted $(<0.5)$ (Hair et al., 1998). These results support the validity of the scales suggested by Bernardo et al. (2012).

Discriminant validation is also acceptable (Table 2). The only issue to consider is the high correlation between perceived value and loyalty, suggesting that these two concepts may be indistinguishable.

\section{Insert Table 2 about here}

The next step was to conduct a structural analysis using structural equations modelling (SEM). The fit indices obtained in the measurement model estimation showed good general fitness. $\chi^{2}$ was 791.6986 with 226 degrees of freedom and a pvalue of $0.000 . \chi^{2} / \mathrm{df}$ was 3.50 , which was under the acceptable limit of 5. RMSEA was 0.053, and the CFI was 0.924. All hypotheses were confirmed at a confidence level of 95\% (Table 3).

\section{Insert Table 3 about here}

Multigroup CFA is used to test the gender invariance, as suggested in the literature. Multigroup CFA is appropriate to test if both the factor structure and the factor loadings are invariant across gender. Moreover, it has the advantage of replicating the CFA across groups, demonstrating the reliability of the factor structure. In the first step, separate CFAs are performed for each group (men and women). The one-factor model provides a good fit for both men $\left(\chi^{2}=517.9242\right.$ with 226 degrees of freedom, $\chi^{2} / \mathrm{df}=$ 2.29, $\mathrm{RMSEA}=0.053, \mathrm{CFI}=0.914)$ and women $\left(\chi^{2}=469.9100\right.$ with 226 degrees of freedom, $\chi^{2} / \mathrm{df}=2.08$, RMSEA $=0.049, \mathrm{CFI}=0.938$ ). Factor loadings are presented in Table 4. Visual comparison of the loadings shows considerable similarities for both men and women.

\section{Insert Table 4 about here}

In the second step, the constrained model is run, where factor loadings are constrained to be equal in the models for men and women. To locate parameters that are non-invariant across groups, we look for probability values associated with the incremental univariate $\chi^{2}$ values that are $<0.05$. Review of these values, as reported in 
Table 4, reveals that all parameters operate equivalently across men and women. From this analysis it can be interfered that both groups perform similarly.

\section{Discussion}

The left hand side of the model was analysed in a previous paper (Bernardo et al., 2012). Here, hypothesis 1 and 2 are confirmed, as both functional quality and hedonic quality have a positive influence on perceived value, however, they behave differently (Ho \& Lee, 2007; Bernardo et al., 2012). Compared to the hedonic dimension, functional quality dimension (efficiency, system availability; fulfilment, and privacy) impacts greatly on perceived value. In the context of e-commerce this finding is of great importance, revealing that having an appealing and friendly user website is not sufficient. Websites or online platforms should be as clear as possible, providing the correct information at the right place. As the service will be contracted employing an online transaction, the functional quality of the website will be highly tied with the perceived value. As for hypothesis 3, results confirm that higher levels of perceived value in a website have a positive and significant effect on loyalty. This finding is in line with that of previous studies in the same industry such as the works of Gallarza and Gill (2006) and Bernardo et al. (2012), revealing that e-quality is an important driver to achieve higher levels of loyalty.

In terms of practical implications, we posit that managers should pay attention to both dimensions of quality in their marketing plans. Both dimensions have been shown to be positively related to higher levels of perceived value, a construct which in turn is positively related to loyalty.

As for the connection between loyalty and behaviour the proposed reveals that, despite the path and its associated t-statistic are low, there is a weak but statistically significant relationship. These results show that there might be other factors, not included here, that could influence customer behaviour. Additional research is required to further investigate on these factors.

Finally, gender differences are also examined; nevertheless, results suggest that men and women have a similar behaviour. Accordingly, no significant gender differences are found in any of the relationships tested in the model under study. From a managerial perspective, these results indicate that there is no need to conduct different marketing strategies across gender in online websites, supporting the argument that 
online gender is a performance that is hidden by the technological veil (Davis et al., 2014).

This study has several additional managerial implications. First, the findings highlight the need for e-service providers to invest in quality. To increase quality among website travel agencies, it is important to pay attention to factors such as security, ease of use, graphic style, reliability and responsiveness (Sousa and Voss, 2012). Managers should also be aware that the current and potential customers are learning and changing their needs. Consequently, websites have to be ready for incorporating changes at any time. Second, the hedonic dimension is relevant to reformulate e-strategies to maintain competitive advantages in the long term. Customers want to enjoy the experience of buying a travel pack service. This means that the hedonic dimension of quality is highlighted when the utilitarian dimension is achieved. The hedonic dimension is therefore key to adding high value to customers and should help to increase sales. Thus, a direct consequence is that managers should reinforce this dimension and include it in their business strategy. Nevertheless, it is important to highlight that the hedonic dimension should be enhanced alongside with the functional dimension, otherwise, the website would not fulfil the basic requirements users expect.

All in all, this study complements previous works in the e-commerce and consumer behaviour literature. Similar results were found by Boshoff (2007). While the relationship between e-quality and perceived value and between perceived value and loyalty are well known, the antecedents of e-consumer behaviour, to a point, are still unknown. Analogous findings were observed in Marimon et al. (2010), specifically in the e-retailer setting. In this study, the authors found that 'loyalty' was influencing 'actual purchases', and provided empirical confirmation of the final link in the chain between the dimensions of e-quality and financial turnover, which had not been investigated in previous studies. Similar to our results, the R-squared for 'actual purchases' was quite low, suggesting that other factors might play a role and need to be included in a more comprehensive model.

\section{Concluding remarks}

This study aims at expanding the model developed by Bernardo et al. (2012) by adding a final step in the value chain from service quality to loyalty: customer behaviour. The empirical application considers the e-commerce context, and particularly, online travel agencies. As for the key findings, the results validate the inclusion of this last step in the 
value chain, corroborating that loyalty is positively related with actual purchase behaviour. Contrary to expected, gender differences are not found in any of the relationships tested.

There are two main limitations of this research that should be considered. One limitation relates to the size and breadth of the simple, which is similar to that of other empirical studies. The second limitation refers to the geographical origin of the sample (Spanish consumers of online travel agencies). Future studies may focus on comparisons between different countries, examining potentially different approaches among travel agencies, depending on their geographical location. Additionally, this study can be replicated and complemented in other service industries. Both crosssectional and longitudinal studies could also extend the validity of the results.

The extant literature is in need of antecedents of actual behaviour and future research is needed in this area. Further studies might also include additional variables to explain consumer behaviour that helps to better understand the relationship between quality (in its multiple dimensions) and consumer behaviour. It is also suggested to increase the emphasis on consumer behaviour depending on the type of product, brand or travel destination. Other future research avenues might consider analysing the impact of the recovery action of the provider in case of failure or complaint. Both scholars and managers are increasingly giving attention to this relationship. Indeed, recent studies have been conducted analysing how service recovery programs enable to maintain satisfied and loyal customers (Sousa and Voss, 2012).

\section{REFERENCES}

Alonso-Almeida, M.M., Bernardo, M., Llach, J., and Marimon, F. (2014). "Building loyalty through functional and hedonic quality". Industrial Management \& Data Systems, Vol. 114 No. 3, pp. 387-404.

Anderson, E.W. and Srinivasan, S.S. (2003), "E-satisfaction and E-loyalty: A contingent framework", Psychology \& Marketing, Vol. 20 No. 2, pp. 123-138.

Bartel Sheehan, K. (1999), "An investigation of gender differences in on-line privacy concerns and resultant behaviors", Journal of Interactive Marketing, Vol. 13No. 4, pp. 24-38.

Bernardo, M., Marimon, F. and Alonso-Almeida, M. (2012), "Functional quality and hedonic quality: A study of the dimensions of e-service quality in online travel agencies", Information \& Management, Vol. 49 No. 7-8, pp. 342-347. 
Boshoff, C. (2007), "A psychometric assessment of E-S-QUAL: A scale to measure electronic service quality", Journal of Electronic Commerce Research, Vol. 8 No. 1, pp. 101-115.

Bowen, J.T. and Shoemaker, S. (1998), "Loyalty: A strategic commitment", Cornell Hotel and Restaurant Administration Quarterly, Vol. 39 No. 1, pp. 12-25.

Bridges, E. and Florsheim, R. (2008), "Hedonic and utilitarian shopping goals: the online experience", Journal of Business Research, Vol. 61 No. 4, pp. 309-314.

Carlson, J. and O'Cass, A. (2010), "Exploring the relationships between e-service quality, satisfaction, attitudes and behaviours in content-driven e-service web sites", Journal of Services Marketing, Vol. 24 No. 2, pp. 112-127.

Chang, H.H., Wang, Y.H. and Yang, W.Y. (2009), "The impact of e-service quality, customer satisfaction and loyalty on e-marketing: Moderating effect of perceived value", Total Quality Management, Vol. 20 No. 4, pp. 423-443.

Chi, H.K., Yeh, H.R. and Yang, Y.T. (2009), "The impact of brand awareness on consumer purchase intention: The mediating effect of perceived quality and brand loyalty”, Journal of International Management Studies, Vol. 4 No. 1, pp. 135-144.

Chiou, J. and Shen, C. (2006), "The effects of satisfaction, opportunism, and asset specificity on customers' loyalty intention toward internet portal sites", International Journal of Service Industry Management, Vol. 17 No. 1, pp. 7-22.

Chitturi, R., Raghunathan, R. and Mahajan, V. (2008), "Delight by design: the role of hedonic versus utilitarian benefits", Journal of Marketing, Vol. 72 No. 3, pp. 48-63.

Chiu, C.M., Wang, E.T., Fang, Y.H. and Huang, H.Y. (2014), "Understanding customers' repeat purchase intentions in B2C e-commerce: the roles of utilitarian value, hedonic value and perceived risk", Information Systems Journal, Vol. 24, No. 1, pp. 85-114.

Cristobal, E., Flavián, C. and Guinaliu, M. (2007), "Perceived e-service quality (PeSQ): measurement validation and effects on consumer satisfaction and web site loyalty", Managing Service Quality, Vol. 17 No. 3, pp. 317-340.

Cyr, D., Bonanni, C., Bowes, J., and Ilsever, J. (2005), "Beyond trust: web site design preferences across cultures", Journal of Global Information Management, Vol. 13 No. 4, pp. 25-54.

Davis, R., Lang, B., and San Diego, J. (2014). "How gender affects the relationship between hedonic shopping motivation and purchase intentions?", Journal of Consumer Behaviour, Vol. 13 No. 1, pp. 18-30. 
Devaraj, S., Fan, M. and Kohli, R. (2002), Antecedents of B2C channel satisfaction andpreference: alidating e-commerce metrics, Information System Research, Vol. 13 No. 3, pp. 316-333.

Enzmann, M. and Schneider, M. (2005), "Improving customer retention in e-commerce through a secure and privacy-enhanced loyalty system”, Information Systems Frontiers, Vol. 7 No. 4-5, pp. 350-370.

Forsythe, S., Liu, C., Shannon, D. and Gardner, L.C. (2006), "Development of a scale to measure the perceived benefits and risks of online shopping", Journal of Interactive Marketing, Vol. 20 No. 2, pp. 55-75.

Fuentes-Blasco, M., Saura, I.G., Berenguer-Contrí, G. and Moliner-Velázquez, B. (2010), "Measuring the antecedents of e-loyalty and the effect of switching costs on website”, The Service Industries Journal, Vol. 30 No. 11, pp. 1837-1852.

Gallarza, M.G. and Gil Saura, I. (2006), "Value dimensions, perceived value, satisfaction and loyalty: an investigation of university students' travel behavior", Tourism management, Vol. 27 No. 3, pp. 437-452.

Guo, Y. and Barnes, S. (2009), "Virtual item purchase behavior in virtual worlds: an exploratory investigation", Electronic Commerce Research, Vol. 9 No. 1-2, pp. 77 96.

Hair, R., Anderson, R., Tatham, R. and Black, W. (1998), Multivariate data analysis. 5th ed, Prentice Hall International, Upper Saddle River.

Hausman, A.V. and Siekpe, J.S. (2009), "The effect of web interface features on consumer online purchase intentions", Journal of Business Research, Vol. 62 No. 1, pp. 5-13.

Hawes, J.M. and Lumpkin, J.R. (1984), "Understanding the shopper", Journal of the Academy of Marketing Science, Vol. 12 No. 4, pp. 200-218.

Hirschman, E.C. and Holbrook, M.B. (1982), "Hedonic consumption: emerging concepts, methods and propositions", The Journal of Marketing, Vol. 46 No. 3, pp. 92-101.

Ho, C.I., and Lee, Y.L. (2007). “The development of an e-travel service quality scale”. Tourism Management, Vol. 28 No. 6, pp. 1434-1449.

Huang, L. (2008), "Exploring the determinants of e-loyalty among travel agencies", Service Industries Journal, Vol. 28 No. 2, pp. 239-254. 
Iliachenko, E. (2006), Electronic service quality (e-SQ) in tourism: development of a scale for the assessment of e-SQ of tourism websites, $\mathrm{PhD}$ Thesis, Luleå Tekniska Universitet, Sweeden.

Jeong, M., Oh, H. and Gregoire, M. (2003), “Conceptualizing web site quality and its consequences in the lodging industry", International Journal of Hospitality Management, Vol. 22 No. 2, pp. 161-175.

Kim, W.G., Lee, C. and Hiemstra, S.J. (2004), "Effects of an online virtual community on customer loyalty and travel product purchases", Tourism Management, Vol. 25 No. 3, pp. 343-355.

Kim, H-b., Kim, T. and Shin, S.W. (2009), "Modeling roles of subjective norms and etrust in customers' acceptance of airline B2C ecommerce websites", Tourism \& Management, Vol. 30 No. 2, pp. 266-277.

Kolsaker, A. and Payne, C. (2002), "Engendering trust in e-commerce: a study of gender-based concerns", Marketing Intelligence \& Planning, Vol. 20 No. 4, pp. 206-214.

Kumar, P. and Varshney, S. (2012), "Gendered scholarship: exploring the implications for consumer behaviour research". Equality, Diversity and Inclusion: An International Journal, Vol. 31 No. 7, pp. 612-632.

Kuo, Y.F. (2003), “A study on service quality of virtual community web sites", Total Quality Management, Vol. 14 No. 4, pp. 461-473.

Lang, T.C. (2000), "The effect of the Internet on travel consumer purchasing behaviour and implications for travel agencies”, Journal of Vacation Marketing, Vol. 6 No. 4, pp. 368-385.

Lee, G.G. and Lin, H.F. (2005), "Customer perceptions of e-service quality in online shopping”, International Journal of Retail \& Distribution Management, Vol. 33 No. 2, pp. 161-176.

Lian, J.W. and Yen, D.C. (2014), "Online shopping drivers and barriers for older adults: Age and gender differences", Computers in Human Behavior, Vol. 37 No. August, pp. 133-143.

Liu, C. and Arnett, K.P. (2000), "Exploring the factors associated with web site success in the context of electronic commerce", Information \& Management, Vol. 38 No. 1, pp. 23-33.

Luarn, P. and Lin, H.H. (2003), “A Customer Loyalty Model for E-Service Context”, Journal of Electronic Commerce Research, Vol. 4 No. 4, pp. 156-167. 
Macdonald, E.K. and Sharp, B.M. (2000), "Brand awareness effects on consumer decision making for a common, repeat purchase product: A replication", Journal of Business Research, Vol. 48 No. 1, pp. 5-15.

Madu, C.N. and Madu, A.A. (2002), "Dimensions of e-quality", International Journal of Quality \& Reliability Management, Vol. 19 No. 3, pp. 246-258.

Marimon, F., Vidgen, R., Barnes, S. and Cristobal, E. (2010), "Purchasing behaviour in an online supermarket: the applicability of E-S-QUAL", International Journal of Market Research, Vol. 52 No. 1, pp. 111-129.

Marimon, F., Petnji Yaya, L. and Casadesus Fa, M. (2012), "Impact of e-Quality and service recovery on loyalty: A study of e-banking in Spain", Total Quality Management \& Business Excellence, Vol. 23 No. 7-8, pp. 769-787.

Moliner, M.A., Sánchez, J., Rodríguez, R.M. and Callarisa, L. (2007), "Relationship quality with a travel agency: The influence of the postpurchase perceived value of a tourism package", Tourism and Hospitality Research, Vol. 7 No. 3-4, pp. 194-211.

Mouakket, S. and Al-hawari, M.A. (2012), "Examining the antecedents of e-loyalty intention in an online reservation environment", The Journal of High Technology Management Research, Vol. 23 No. 1, pp. 46-57.

Nam, J., Ekinci, Y. and Whyatt, G. (2011), "Brand equity, brand loyalty and consumer satisfaction", Annals of Tourism Research, Vol. 38 No. 3, pp. 1009-1030.

Palan, K.M. (2001), "Gender identity in consumer behavior research: a literature review and research agenda", Academy of Marketing Science Review, Vol. 10 No. 2001, pp. $1-31$.

Parasuraman, A., Zeithaml, V. and Berry, L. (1988), "SERVQUAL: A multiple-item scale for measuring consumer perceptions of service quality”, Journal of Retailing, Vol. 64 No. 1, pp. 12-40.

Parasuraman, A., Zeithaml, V. and Malhotra, A. (2005), "E-S-Qual: A multiple-item scale for assessing electronic service quality", Journal of Service Research, Vol. 7 No. 3, pp. 213-233.

Petnji Yaya, L., Marimon, F. and Casadesus Fa, M. (2012), “Assessing e-service quality: the current state of E-S-QUAL", Total Quality Management \& Business Excellence, Vol. 23 No. 12, pp. 1363-1378.

Ribbink, D., van Riel, A., Liljander, V. and Streukens, S. (2004), “Comfort your online customer: quality, trust, and loyalty on the internet”, Managing Service Quality, Vol. 14 No. 6, pp. 446-56. 
Rodgers, S. and Harris, M.A. (2003), "Gender and E-Commerce: An Exploratory Study", Journal of Advertising Research, Vol. 43 No. 3, pp. 322-329.

Solano-Lorente, M., Martínez-Caro, E. and Cegarra-Navarro, J.G. (2013), "Designing a Framework to Develop eLoyalty for Online Healthcare Services", Electronic Journal of Knowledge Management, Vol. 11 No. 1, pp. 107-115.

Sousa, R. and Voss, C. (2012), "The impacts of e-service quality on customer behaviour in multi-channel e-services", Total Quality Management \& Business Excellence, Vol. 23 No. 7-8, pp. 789-806.

Sproles, G.B. and Kendall, E.L. (1986), “A methodology for profiling consumers' decision making styles", The Journal for Consumer Affairs, Vol. 20 No. 2, pp. 267279.

Vázquez-Casielles, R.V., del Río-Lanza, A.B. and Suárez-Álvarez, L. (2009), "Las agencias de viaje virtuales: ¿Cómo analizar la calidad de e-servicio y sus efectos sobre la satisfacción del cliente?", Universia Business Review, Vol. 24, pp. 122143.

Venkatesh, V. and Davis, F.F. (2000), "A theoretical extension of the technology acceptance model: four longitudinal field studies", Management Science, Vol. 46 No. 2, pp. 186-204.

Wang, Y., Yu, Q. and Fesenmaier, D.R. (2002), "Defining the virtual tourist community: implications for tourism marketing", Tourism management, Vol. 23 No. 4, pp. 407-417.

Weiser, E.B. (2000), "Gender differences in Internet use patterns and Internet application preferences: A two-sample comparison", CyberPsychology and Behavior, Vol. 3 No. 2, pp. 167-178.

Yang, Z. and Jun, M. (2002), “Consumer perception of e-service quality: from internet purchaser and non-purchaser perspectives”, Journal of Business Strategies, Vol. 19 No. 1, pp. 19-41.

Zeithaml, V.A., Parasuraman, A. and Malhotra, A. (2002), "Service quality delivery through web sites: a critical review of extant knowledge", Journal of the Academy of Marketing Science, Vol. 30 No. 4, pp. 362-375.

Zha, X., Zhang, J., Yan, Y. and Xiao, Z. (2014), "User perceptions of e-quality of and affinity with virtual communities: The effect of individual differences", Computers in Human Behavior, Vol. 38 No. 2014, pp. 185-195. 


\section{List of Tables and Figures}

Table 1. Reliability of the scales

\begin{tabular}{|c|c|c|c|}
\hline \multicolumn{4}{|c|}{ Cronbach's alpha $=0.937 ; \mathrm{CR}=0.940 ; \mathrm{AVE}=0.636$} \\
\hline & item & load & t-statistic \\
\hline 1 & This site makes it easy to find what I need & 0.811 & \\
\hline 2 & It is easy to navigate on this site & 0.815 & $29.405(*)$ \\
\hline 3 & This site enables me to complete a transaction quickly & 0.824 & $30.820(*)$ \\
\hline 4 & Information on this site is well presented & 0.782 & $28.198(*)$ \\
\hline 5 & The pages load quickly on this site & 0.785 & $25.592(*)$ \\
\hline 6 & It is easy to get onto this site quickly & 0.802 & $22.851(*)$ \\
\hline 7 & This site is always available for business & 0.762 & $23.199(*)$ \\
\hline 8 & This site makes items available for delivery within a suitable time frame & 0.791 & $21.809(*)$ \\
\hline 9 & This site delivers the items ordered & 0.806 & $26.375(*)$ \\
\hline \multicolumn{4}{|c|}{ F2.- Hedonic Quality } \\
\hline \multicolumn{3}{|c|}{ Cronbach's alpha $=0.879 ; \mathrm{CR}=0.883 ; \mathrm{AVE}=0.604$} & t-statistic \\
\hline 1 & $\begin{array}{l}\text { I enjoy the multimedia information, suggestions, and recommendations } \\
\text { provided to the customer on this website }\end{array}$ & 0.750 & \\
\hline 2 & I think it is great fun to browse this site & 0.862 & $27.916(*)$ \\
\hline 3 & When interacting with this site, I do not realize how much time has elapsed & 0.799 & $26.403(*)$ \\
\hline 4 & I enjoy sharing comments and experiences from other travelers & 0.656 & $21.596(*)$ \\
\hline 5 & I really enjoy shopping at this website of the travel agency & 0.805 & $25.511(*)$ \\
\hline \multicolumn{4}{|c|}{ F3.- Perceived Value } \\
\hline & Item & load & t-statistic \\
\hline 1 & The prices of the products and services available at this site are economical & 0.651 & \\
\hline 2 & Overall, using this site is convenient & 0.807 & $19.671(*)$ \\
\hline 3 & This site gives me a feeling of being in control & 0.754 & $17.414(*)$ \\
\hline 4 & Overall, this site gives me value for my money and effort & 0.777 & $22.636(*)$ \\
\hline 5 & The experience of this site has satisfied my needs and wants & 0.840 & $20.865(*)$ \\
\hline \multicolumn{4}{|c|}{ F4.- Loyalty } \\
\hline & item & load & t-statistic \\
\hline 1 & I encourage friends and relatives to do business with this site & 0.678 & \\
\hline 2 & I say positive things about this site to other people & 0.708 & $24.655(*)$ \\
\hline 3 & I will do more business with this site in the next few years & 0.809 & $20.169(*)$ \\
\hline
\end{tabular}

CR: Composite Reliability

AVE: Average Variance Extracted

(*) significant at 5\% level

Based on Bernardo et al. (2012) 
Table 2. Bivariate correlations between main constructs and the square root of Average Variance Extracted

\begin{tabular}{|l|c|c|c|c|}
\hline & 1 & 2 & 3 & 4 \\
\hline 1. Functional quality & 0.797 & & & \\
\hline 2. Hedonic quality & 0.443 & 0.777 & & \\
\hline 3. Perceived value & 0.611 & 0.530 & 0.769 & \\
\hline 4. Loyalty & 0.568 & 0.516 & 0.798 & 0.733 \\
\hline
\end{tabular}

The square roots of AVE are in bold Italic font style on the main diagonal and the correlations between latent variables follow below.

Table 3. Hypothesis results for the structural model

\begin{tabular}{|c|l|c|c|c|}
\hline \multicolumn{2}{|c|}{ Hypotheses } & $\begin{array}{c}\text { Path coefficient } \\
\text { (standardised } \\
\text { solution) }\end{array}$ & t-value ${ }^{\mid *}$ () & Hypothesis \\
\hline H1 & Functional Quality $\rightarrow$ Perceived value & 0.496 & 7.814 & Accepted \\
\hline H2 & Hedonic Quality $\rightarrow$ Perceived value & 0.368 & 7.977 & Accepted \\
\hline H3 & Perceived value $\rightarrow$ Loyalty & 0.958 & 16.615 & Accepted \\
\hline H4 & Loyalty $\rightarrow$ Behaviour & 0.088 & 2.235 & Accepted \\
\hline & $\begin{array}{l}\text { Covariance between Functional Quality and Hedonic } \\
\text { Quality }\end{array}$ & 0.483 & 9.728 & Accepted \\
\hline
\end{tabular}

(*) Significant at 5\% level

Table 4. Paths for each group and univariate increment analysis

\begin{tabular}{|l|c|c|c|c|}
\hline & \multirow{2}{*}{$\begin{array}{c}\text { Paths } \\
(\text { Men }\end{array}$} & \multirow{2}{*}{$\begin{array}{c}\text { Paths } \\
(\text { Women }\end{array}$} & \multicolumn{2}{|c|}{ Univariate increment } \\
\cline { 5 - 6 } & subsample) & subsample) & $\chi^{2}$ & Probability \\
\hline Functional Quality $\rightarrow$ Perceived value & $0.477(*)$ & $0.511\left(^{*}\right)$ & 0.321 & 0.571 \\
\hline Hedonic Quality $\rightarrow$ Perceived value & $0.343(*)$ & $0.388\left(^{*}\right)$ & 1.115 & 0.291 \\
\hline Perceived value $\rightarrow$ Loyalty & $0.940(*)$ & $0.968\left(^{*}\right)$ & 0.656 & 0.418 \\
\hline Loyalty $\rightarrow$ Behaviour & $0.029\left(^{*}\right)$ & $0.088(*)$ & 0.410 & 0.522 \\
\hline
\end{tabular}

(*) Significant at $5 \%$ level 
Figure 1. Research model

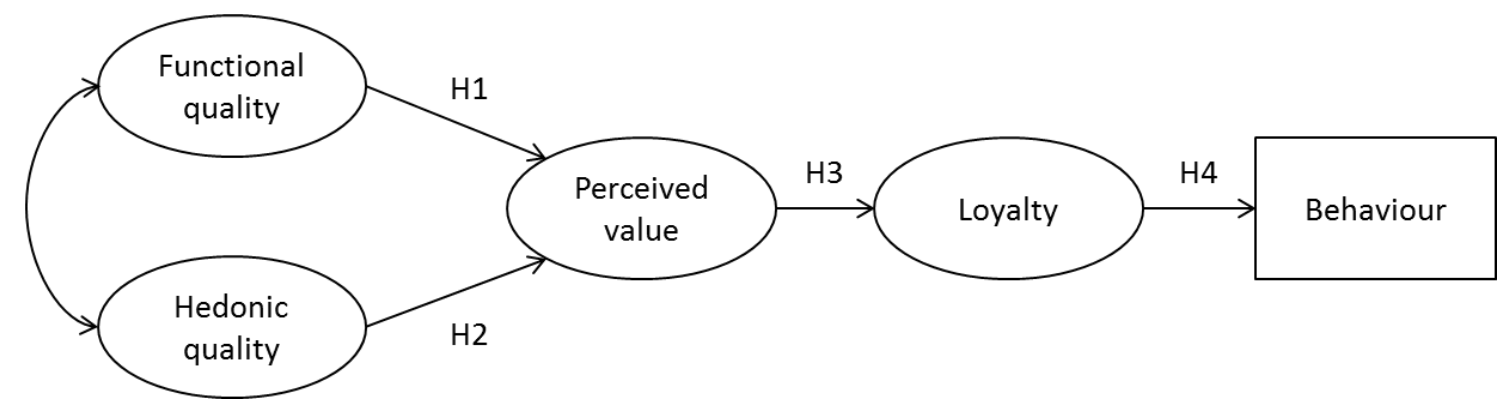

